\title{
PENGARUH AKUPRESUR TERHADAP INTENSITAS NYERI PERSALINAN KALA I FASE AKTIF DI BIDAN PRAKTIK MANDIRI RAHMADINA ROSA TAHUN 2019
}

\author{
Berliana Irianti, Nelly Karlinah \\ STIKes Hang Tuah Pekanbaru
}

\begin{abstract}
The birth process can cause discomfort and pain, therefore the experience of childbirth has great potential for satisfying pain relief. Managing labor pain requires maternal love care which is in accordance with WHO documents. Various attempts were made to reduce pain during labor, both pharmacologically and non-pharmacologically. non-pharmacological methods are cheaper, simpler, effective and without any adverse effects. This can be done as an effort to provide comfort to mothers who give birth and midwives as health workers also play a very important role in this.

The aim of the study was to determine the effect of acupressure techniques on the intensity of pain in the active phase of labor. The research was conducted at the Practice of Midwives Mandiri Rahmadina Rosa. This type of experimental research with post test only control group design method of consecutive sampling is the sample size of 20 respondents per group with a total sample of 40 respondents. Data were analyzed univariate and bivariate using the Chi-Square test. The proportion of pain intensity in the moderate category in the acupressure intervention group was greater than the control group at $4 \mathrm{~cm}$ cervical opening. based on statistical tests there is a significant effect where the value of $p$ $=0.011$. In conclusion the effect of acupressure is better used at a $4 \mathrm{~cm}$ opening,
\end{abstract}

Keywords: Childbirth, ACupressure, Pain

\begin{abstract}
ABSTRAK
Proses persalinan dapat menimbulkan ketidaknyamanan dan nyeri, oleh karena itu pengalaman melahirkan mempunyai potensi yang besar untuk mendapat pereda nyeri yang memuaskan. Mengelola nyeri persalinan dibutuhkan asuhan sayang ibu dimana sesuai dengan dokumen WHO. Berbagai upaya dilakukan untuk menurunkan nyeri pada persalinan, baik secara farmakologi maupun nonfarmakologi. metode nonfarmakologi lebih murah, simpel, efektif dan tanpa efek yang merugikan. Hal ini dapat dilakukan sebagai upaya yang dilakukan untuk memberikan kenyamanan pada ibu bersalin dan bidan sebagai salah satu tenaga kesehatan juga sangat berperan dalam hal tersebut.

Tujuan penelitian untuk mengetahui pengaruh tehnik akupresur terhadap intensitas nyeri persalinan kala I fase aktif. Penelitian dilakukan di Praktik Bidan Mandiri Rahmadina Rosa. Jenis penelitian eksperimental dengan post test only control group desain cara pengambilan sampel consecutive sampling jumlah sampel 20 responden setiap kelompok total sampel 40 responden. Data dianalisis univariat dan bivariat menggunakan uji ChiSquare. Proporsi intensitas nyeri dengan kategori sedang pada kelompok intervensi akupresur lebih besar dari pada kelompok kontrol pada pembukaan serviks $4 \mathrm{~cm}$. berdasarkan uji statistik terdapat pengaruh bermakna dimana nilai $\mathrm{p}=0,011$. Kesimpulan pengaruh akupresur lebih baik digunakan pada pembukaan $4 \mathrm{~cm}$,
\end{abstract}

Kata Kunci : Persalinan, AKupresur, Nyeri 


\section{PENDAHULUAN}

Proses persalinan dapat menimbulkan ketidaknyamanan dan nyeri, oleh karena itu pengalaman melahirkan mempunyai potensi yang besar untuk mendapat pereda nyeri yang memuaskan (Norwitz, 2007; Reeder, 2013).

Mengelola nyeri persalinan dibutuhkan asuhan sayang ibu dimana sesuai dengan dokumen WHO menjelaskan salah satu cara untuk memberikan asuhan yang bersifat sayang ibu disebut dengan Safe Motherhood yang mempunyai misi untuk mempromosikan kesempurnaan model asuhan persalinan yang dapat meningkatkan hasil kelahiran, model asuhan kebidanan ini mendukung dan melindungi proses kelahiran normal.

Berbagai upaya dilakukan untuk menurunkan nyeri pada persalinan, baik secara farmakologi maupun nonfarmakologi. metode nonfarmakologi lebih murah, simpel, efektif dan tanpa efek yang merugikan. Hal ini dapat dilakukan sebagai upaya yang dilakukan untuk memberikan kenyamanan pada ibu bersalin dan bidan sebagai salah satu tenaga kesehatan juga sangat berperan dalam hal tersebut. Pengaruh akupresur terhadap penurunan nyeri persalinan ini telah diuji beberapa ahli dalam beberapa penelitian.
Akupresur secara signifikan berpengaruh terhadap pengurangan rasa nyeri persalinan pada kala I persalinan tetapi tidak menunjukkan pengaruh terhadap kontraksi uterus.

Metode pengurangan nyeri ini belum tersosialisasikan keseluruh wilayah Indonesia, terutama pengurangan nyeri persalinan, fakta dilapangan metode pengurangan nyeri akupresur ini belum pernah dilakukan atau dikenal oleh petugas kesehatan itu sendiri, sering didapatkan metode pengurangan nyeri cenderung menggunakan obat-obatan untuk mengurangi rasa nyeri saat persalinan.

\section{METODE}

Jenis Penelitian ini merupakan penelitian kuantitatif dengan rancangan eksperimental dengan post test only control group desain. Kelompok yang diteliti di bagi menjadi kelompok kontrol dan eksperimental yaitu kelompok akupresur.

Populasi dalam penelitian ini adalah semua ibu inpartu kala I fase aktif di Praktik Bidan Mandiri Rahmadina Rosa. Sampel penelitian adalah bagian dari populasi yang memenuhi kriteria inklusi dan eklusi di PMB Rahmadina Rosa 
Tehnik pengambilan sampel consecutive sampling yaitu semua subjek yang datang secara berurutan dan memenuhi kriteria inklusi dimasukkan dalam penelitian sampai jumlah sampel yang diperlukan terpenuhi. Analisis data yang digunakan adalah analisi univariat dan bivariat

HASIL

\section{Distribusi Frekuensi Responden pada Kelompok Akupresur, dan Kontrol}

\begin{tabular}{lcccc}
\hline \multirow{2}{*}{$\begin{array}{c}\text { Karakteristik } \\
\text { Responden }\end{array}$} & \multicolumn{2}{c}{ Akupresur } & \multicolumn{2}{c}{ Kontrol } \\
\cline { 2 - 5 } & $\mathrm{F}$ & $\%$ & $\mathrm{f}$ & $\%$ \\
\hline Umur & & & & \\
20-25 tahun & 14 & 70 & 12 & 60 \\
26-30 tahun & 5 & 25 & 8 & 40 \\
$31-35$ tahun & 1 & 5 & 0 & 0 \\
\hline Pendidikan & & & & \\
SD & 3 & 15 & 0 & 0 \\
SMP & 1 & 5 & 4 & 20 \\
SMA & 10 & 50 & 14 & 70 \\
PT & 6 & 30 & 2 & 10 \\
\hline Pekerjaan & & & & \\
Tidak bekerja & 10 & 50 & 17 & 85 \\
Bekerja & 10 & 50 & 3 & 15 \\
\hline Suku & & & & \\
Melayu & 12 & 60 & 11 & 55 \\
Jawa & 8 & 40 & 9 & 45 \\
\hline
\end{tabular}

2. Pengaruh Akupresur terhadap Intensitas Nyeri Persalinan Kala I Fase Aktif pada Pembukaan $4 \mathrm{~cm}$

\begin{tabular}{cccccc} 
Intensitas & \multicolumn{4}{c}{ Akupresur } & \\
\cline { 2 - 5 } $\begin{array}{c}\text { Nyeri } \\
\text { Pembukaa } \\
4 \mathrm{~cm}\end{array}$ & Intervensi & \multicolumn{2}{c}{ Kontrol } & & \\
\cline { 2 - 5 } & $\mathbf{f}$ & $\mathbf{\%}$ & $\mathbf{f}$ & $\mathbf{\%}$ & \\
\cline { 2 - 5 } Sedang & 15 & 75 & 6 & 30 & \\
Berat & 5 & 25 & 14 & 70 & 0,011 \\
\hline Jumlah & $\mathbf{2 0}$ & $\mathbf{1 0 0}$ & $\mathbf{2 0}$ & $\mathbf{1 0 0}$ & \\
\hline
\end{tabular}

3. Pengaruh Akupresur terhadap Intensitas Nyeri Persalinan Kala I Fase Aktif pada Pembukaan $8 \mathrm{~cm}$

\begin{tabular}{cccccc} 
& \multicolumn{4}{c}{ Akupresur } & \\
\cline { 2 - 4 } $\begin{array}{c}\text { Intensitas } \\
\text { Nyeri }\end{array}$ & Intervensi & Kontrol & & \\
\cline { 2 - 4 } $\begin{array}{c}\text { Pembukaan } \\
8 \mathrm{~cm}\end{array}$ & $\mathrm{f}$ & $\%$ & $\mathrm{f}$ & $\%$ & \\
& & & & & \\
\cline { 2 - 5 } Sedang & 8 & 40 & 4 & 20 & \\
Berat & 12 & 60 & 16 & 80 & 0,301 \\
\hline Jumlah & 20 & 100 & 20 & 100 & \\
\hline
\end{tabular}

\section{PEMBAHASAN}

Intensitas nyeri di observasi sebanyak 2 kali tiap kelompok akupresur dan kontrol yaitu 1 kali pada pembukaan serviks $4 \mathrm{~cm}$ dan 1 kali pada pembukaan serviks $8 \mathrm{~cm}$. Pengukuran intensitas nyeri diukur menggunakan skala Numerical Rating Scale (NRS).

\section{Karakteristik Responden Penelitian}

Mayoritas terdapat pada umur 20-25 tahun dimana pada umur tersebut beresiko rendah. Menurut teori ibu yang melahirkan pertama kali pada umur tua umumnya akan mengalami persalinan yang lebih lama dan merasakan lebih nyeri dibandingkan ibu yang masih muda (Bobak, 2004).

Mayoritas pendidikan SMA, dilihat dari segi pekerjaan mayoritas tidak bekerja, dan mayoritas suku pada penelitian ini adalah suku melayu. Menurut Davidson dkk (2008) faktorfaktor yang mempengaruhi respon terhadap nyeri persalinan meliputi pendidikan, kepercayaan, budaya, 
kelelahan dan gangguan tidur, makna nyeri, pengalaman sebelumnya, kecemasan dan adanya tehnik pengurangan nyeri non farmakologi.

\section{Akupresur}

Hasil penelitian ini terdapat perbedaan pengaruh intensitas nyeri pada kelompok dilakukan intervensi akupresur dan kontrol pada pembukaan serviks $4 \mathrm{~cm}$, dimana pada kelompok intervensi intensitas nyeri sebagian besar kategori sedang sedangkan pada kelompok kontrol intensitas nyeri myoritas kategori berat. Hasil uji statistik berdasarkan nilai $\mathrm{p}<0,05$ yang berarti terdapat pengaruh bermakna antara dilakukan intervensi akupresur dan kontrol terhadap intensitas nyeri persalinan kala I fase aktif.

Nyeri yang dirasakan pada pembukaan serviks $4 \mathrm{~cm}$ disebabkan oleh perubahan serviks dan iskemia rahim, nyeri pada pembukaan $4 \mathrm{~cm}$ ini bersifat viseral. Nyeri ini berasal dari bagian bawah abdomen dan menyebar ke daerah lumbar punggung dan menurun kepaha. Dari hasil penelitian terdapat hubungan yang bermakna dilakukan intervensi akupresur dengan kelompok kontrol pada pembukaan serviks $4 \mathrm{~cm}$, menurut asumsi peneliti nyeri pada pembukaan $4 \mathrm{~cm}$ bersifat viseral dimana nyeri belum tertuju pada suatu tempat, jadi dengan adanya penekanan atau sentuhan pada titik Sp6 dan Li4 dapat meningkatkan rasa kenyamanan pada ibu. Nyeri viseral ini ditimbulkan oleh karena adanya kontraksi uterus dan dilatasi serviks yang dipersyarafi oleh serabut aferen simpatis dan ditransmisikan kemedula spinalis pada segmen T10-L1 (thorakal 10-Lumbal 1) melalui serabut saraf delta dan serabut syaraf $\mathrm{c}$ yang berasal dari dinding lateral dan fundus uteri (Maryunani, 2010; Andarmoyo 2013).

Pada pembukaan serviks $8 \mathrm{~cm}$ dilakukan intervensi akupresur dengan kelompok kontrol didapatkan tidak ada hubungan yang bermaknan dengan nilai $\mathrm{P}>0,05$. Menurut asumsi peneliti, nyeri pada pembukaan serviks $8 \mathrm{~cm}$ bersifat somatik karena mendekati kala II persalinan, nyeri pada pembukaan ini ditransmisikan melalui nervus pundendal yang berasal dari S2 dan S4, pada kala ini intensitas nyerinya terasa lebih nyeri dan sudah terlokalisasi, nyeri pada masa transisi ini diakibatkan oleh tekanan kepala janin pada pelvis, nyeri yang dirasakan bagian bawah punggung, paha dan tungkai kaki, pada areal vagina dan perineum sensasinya seperti tarikan, tekanan, dan kram. Sensasi nyeri ini dibawa dari perineum ke sakrum 2,3,4 oleh saraf pundendal dan untuk mengurangi nyeri ini biasanya diblok 
pada reseptor yang paling bawah, (Maryunani, 2010; Andarmoyo, 2013)

\section{KESIMPULAN}

Berdasarkan dari hasil penelitian yang telah dilakukan, dapat ditarik kesimpulan Ada pengaruh akupresur pada kelompok intervensi dengan kontrol pada pembukaan serviks $4 \mathrm{~cm}$ terhadap intensitas nyeri persalinan kala I fase aktif. Dan Tidak ada pengaruh akupresur pada kelompok intervensi dengan kontrol pada pembukaan serviks $8 \mathrm{~cm}$ terhadap intensitas nyeri persalinan kala I fase aktif

\section{SARAN}

1. Bagi Praktik Kebidanan

Hasil penelitian menunjukkan bahwa Akupresur memberikan manfaat pengurangan nyeri pada persalinan kala I fase aktif, dimana akupresur ini merupakan metode non farmakologi yang dapat digunakan oleh tenaga kesehatan khususnya bidan dalam membantu proses persalinan dengan tujuan mewujudkan meningkatkan kenyamanan pada ibu bersalin kala I fase aktif.

2. Bagi Penelitian Kebidanan

Diharapkan pada penelitian selanjutnya dapat melanjutkan penelitian tentang pengurangan nyeri akupresur pada kala I persalinan dengan menggunakan titik-titik akupresur yang lainnya, mengukur tingkat asietas (kecemasan), stres serta faktor lain yang dapat mempengaruhi persepsi intensitas nyeri persalinan kala I fase aktif.

3. Bagi pengembangan ilmu kebidanan

Penelitian ini dapat digunakan sebagai salah satu sumber yang evidence based dalam ilmu kebidanan khususnya dalam penatalaksanaan tehnik pengurangan nyeri non farmakologi dengan tujuan meningkatkan kenyamanan pada ibu bersalin kala I fase aktif.

4. Bagi pengembangan pendidikan kebidanan

Metode nonfarmakologi Akupresur dapat di sosialisasikan sebagai informasi dan pengetahuan yang efektif dalam pengurangan nyeri persalinan kala I fase aktif, metode ini dapat dimasukkan ke materi tentang tehnik-tehnik nonfarmakologi serta dapat diterapkan dalam kurikulum pendidikan diploma kebidanan dalam materi asuhan persalinan dalam mengurangi rasa nyeri 


\section{DAFTAR PUSTAKA}

Abd El Hamid, N.A.F. Obaya, H. E. \& Hassan M.G.(2012). Effect of Acupressure on Labor Pain and Duration of Among Laboring Women Attending Cairo University Hospital. IOSR Journal of Nursing and Health Science (IOSR-JNHS) Volume I, Issue I (Nov-Dec 2012, pp 08-14. www.iosrjournals.org

Andarmoyo S. (2013). Persalinan Tanpa Nyeri Berlebihan : konsep dan Aplikasi Manajemen Nyeri Persalinan. Editor Rose kusumaning. Yogyakarta : Ar-Ruzz Media.

Bagaskoro S. (2011). Buku Sakti Pijat Untuk Kesehatan Refleksi, Akupresur dan Akupuntur. Yogyakarta : Pinang Merah Publisher.

Brown, Douglas \& Flood (2001). Women's Evaluation of Intrapartum Nonpharmalogical Pain Relief Method Used During Labor. The Journal of Perinatal education.10(3), 1-8

Chung, L., Kuo, S., Huang, C. (2003).

Effects of Li4 and BL 67 Acupressure on labor Pain and Uterine Contraction in the First Stage of Labor. Journal of Nursing Reseach.
Dewi KB, (2011).Hubungan Akupresur Terhadap Tingkat Nyeri dan Lama Persalinan. FK Universitas Indonesia. Thesis. Jakarta.

Departemen Kesehatan (2000). Pedoman Praktis akupresur, Jakarta : Depkes RI (2004). Pedoman Pelatihan Akupresur Untuk Petugas Kesehatan, Jakarta : Depkes RI (2012). Kurikulum dan Modul Orientasi Akupresur Bagi Petugas Puskesmas. Jakarta : Depkes RI.

Kashanian M., Shahali S.(2010). Effects of acupressure at the Sanyinjiao Point (SP6) on the Process of active Phase of Labor in nulliparas Women.The Journal of MaternalFetal and Neonatal Medicine, july ; 23(7) : 638-631

Lee, M, Chang, S. \& Kang, D. (2004). Effect of SP6 Acupressure on labor Pain and Lengt of Delivery Time in Women During Labor.The Journal of Alternative and Complementary Medicine

Maryunani, A. (2010). Nyeri Dalam Persalinan : Tehnik dan cara Penanganannya. Jakarta. Trans Info Medika 